\title{
Lack of biochemical polymorphism in British fallow deer
}

\author{
J. M. Pemberton* \\ and R. H. Smith
}

Wildlife Management Group, Department of Pure and Applied Zoology, University of Reading, Whiteknights, P.O. Box 228, Reading RG6 2AJ

\begin{abstract}
Seven-hundred and ninety-four samples of fallow deer (Dama dama L.) blood or tissue were collected from 37 sites in England and Wales. A selection of these samples was screened for electrophoretic variation at each of 30 loci (minimum of 88 samples per locus). No genetic variation was found. Possible explanations for the lack of polymorphism are discussed. It is suggested that European fallow deer experienced a genetic bottleneck during a period of captivity in Mesolithic or Neolithic times.
\end{abstract}

\section{INTRODUCTION}

Electrophoresis has been used to generate genetic data about a number of deer species. To date at least 70 papers and reports have been written in this field. The information obtained has been used to study genetic differentiation between species (Baccus et al., 1983), subspecies (Gyllensten et al., 1983; Dratch and Gyllensten, in press) and populations (Soldal and Staaland, 1980; Ryman et al., 1980; Gyllensten et al., 1983; Dratch and Gyllensten, in press) and to examine population subdivision, giving insights into dispersal behaviour (Manlove et al., 1976; Ramsey et al., 1979; Chesser et al., 1982). Other authors have sought relationships between performance and genotype (Johns et al., 1977; Smith et al., 1982; Cothran et al., 1983) or changes in genotype frequencies over time (Baccus et al., 1977; Chesser et al., 1982), suggesting the action of natural selection. Among practical uses, the discrimination of species from blood spots or tissue scraps is of value in law enforcement (Oates et al., 1979; Lawton and Sutton, 1981; McClymont et al., 1982) and genetic information is of obvious interest to conservationists, for example in the planning of introductions (Smith et al., 1976; Ryder et al., 1981; Gyllensten et al., 1983). A number of uses for electrophoresis studies can also be envisaged in the growing deer farming industry, ranging from the assessment of genetic differences between lines to paternity testing.

\footnotetext{
* Present address: Department of Zoology, University College London, Gower Street, London WC1E 6BT.
}

Most of the applications mentioned above imply the presence of considerable intraspecific polymorphism in deer, which is certainly true for the four species on which studies have so far concentrated. Most work on the Old World reindeer (Rangifer tarandus tarandus) has been limited to a single locus, transferrin, at which major surveys have each revealed between 7 and 12 alleles (Braend, 1964; Turubanov and Shubin, 1971; Zhurkevich and Fomicheva, 1976; Soldal and Staaland, 1980; Røed, in press). The remaining three species have been surveyed extensively both geographically and in terms of the number of loci screened, and table 1 summarises the principal studies. Points to notice are that none of the species completely lacks detectable variation and that the white-tailed deer shows an apparently higher level of genetic variation than moose, red deer and wapiti. Indeed, all the white-tailed deer populations and some of the moose and wapiti populations studied have average heterozygosities $(H)$ greater than the $H$ for all mammals ( $H=$ $0.033-0.039$ ) derived by various authors (Powell, 1975; Nevo, 1978; Avise and Aquadro, 1982; Baccus et al., 1983) which argues further against the generalisation that large mammals are monomorphic (see Ryman et al., 1980).

The present study was undertaken as a first step towards using electrophoretically-detectable variation to investigate the occurrence of inbreeding in fallow deer (Dama dama L.) populations (Smith, 1979). Previously published 
Table 1 Summary of the most extensive genetic surveys of deer species to date

\begin{tabular}{|c|c|c|c|c|}
\hline Species & $\begin{array}{l}\text { Number (and } \\
\text { location) of } \\
\text { populations } \\
\text { surveyed }\end{array}$ & $\begin{array}{l}\text { Number } \\
\text { of loci } \\
\text { screened }\end{array}$ & $\begin{array}{l}\text { Range of average } \\
\text { heterozygosity } \\
(H) \text { found }\end{array}$ & Reference \\
\hline $\begin{array}{l}\text { white-tailed deer } \\
\text { (Odocoileus virginianus) }\end{array}$ & 8 (S.E. USA) & 35 & $0 \cdot 049-0 \cdot 092$ & Smith et al., in press \\
\hline $\begin{array}{l}\text { moose } \\
\qquad \text { (Alces alces) }\end{array}$ & 18 (Scandinavia) & 23 & $0.006-0.047$ & Ryman et al., 1980 \\
\hline $\begin{array}{l}\text { red deer and wapiti } \\
\text { (Cervus elaphus) }\end{array}$ & $\begin{array}{l}22 \text { (N.W. Europe) } \\
11 \text { (N.W. USA) }\end{array}$ & $\begin{array}{l}34 \\
28\end{array}$ & $\begin{array}{l}0.000-0.031 \\
0.004-0.060\end{array}$ & $\begin{array}{l}\text { Gyllensten et al., } 1983 \\
\text { Dratch and Gyllensten, } \\
\text { in press }\end{array}$ \\
\hline
\end{tabular}

electrophoresis and isoelectric focusing studies of fallow deer include a survey of serum proteins, especially transferrin, by McDougall and Lowe (1968), haemoglobin studies by Maughan and Williams (1967), Butcher and Hawkey (1977) and Lawton and Sutton (1981) and the screening of LDH by Munday et al. (1974). Only the Butcher and Hawkey (1977) study suggested a polymorphism in fallow deer. However, besides the small number of loci screened, all the studies mentioned involved limited sampling of individuals and/or populations. Since initial small surveys of the species shown in table 1 also sometimes failed to reveal variation (e.g., transferrin: Braend, 1962; Johnson, 1968; Seal and Erickson, 1969) the previous fallow deer studies do not necessarily indicate the outcome of a more thorough study. Indeed, given the results of existing large surveys of deer species (see above), the widespread, genetically controlled coat colour polymorphism of British fallow deer (Chapman and Chapman, 1975, pp. 23-31) and a suggestion of genetically determined skeletal variation in this species (Chapman and Chapman, 1969), the present survey was fully expected to reveal genetic variation.

\section{MATERIALS AND METHODS}

Blood and post mortem tissues were collected from fallow deer from the sites in England and Wales shown in fig. 1. In total 794 individual deer from 37 sites were sampled in some way, but we emphasize the heterogeneity of the samples. Blood was obtained by bleeding live deer ( 389 animals), by post mortem sampling ( 280 animals) and by taking aliquots of samples collected by other researchers (43 animals). Post mortem tissue sets consisting of muscle, liver and kidney were collected by stalkers from 179 animals (including 148 which were also blood sampled) while samples of muscle only were obtained from 51 carcasses in a butcher's cold store.

Fig. 1 also gives a rough indication of the number of animals sampled per site which ranged from one (four sites in Berkshire and Hampshire) to 126 (Margam Park, South Wales). The "sites" themselves consisted of 14 more-or-less enclosed parks and 23 areas holding wild fallow deer.

In addition to fallow deer samples, 133 blood samples and 14 post mortem tissue sets were collected from red deer from two sites and blood samples were taken from six muntjac (Muntiacus reevesi) from one site, for comparative purposes.

Blood was collected into heparinised tubes (Vacutainer and Sterilin). Blood samples from live deer and from some freshly shot deer were brought to Reading in a vacuum flask containing melting ice and were processed within 48 hours of collection. Blood samples collected by stalkers were posted to Reading and processed on arrival. After centrifugation ( $3000 \mathrm{rpm}$ for 15 minutes) the plasma was drawn off, separated into aliquots and frozen. All samples were stored at $-30^{\circ} \mathrm{C}$. Approximately $2 \mathrm{ml}$ of the remaining red cells were washed and centrifuged two to three times in $8 \mathrm{ml} 0.85$ per cent $\mathrm{NaCl}$ solution. When a clear supernatant was produced, the red cells were lysed with $1 \mathrm{ml}$ distilled water, divided into aliquots and frozen.

Post mortem tissues collected by stalkers were stored in domestic freezers until retrieved. The samples were brought to Reading in a vacuum flask packed with solid $\mathrm{CO}_{2}$ to prevent thawing. The tissues were kept frozen until immediately before electrophoresis when sections weighing approximately $600 \mathrm{mg}$ were homogenised in an equal volume of distilled water. All homogenising was carried out by hand in a ground glass homogeniser (Gallenkamp) or with a pestle and mortar, when $200 \mathrm{mg}$ sterilised sand was added to aid grinding. 


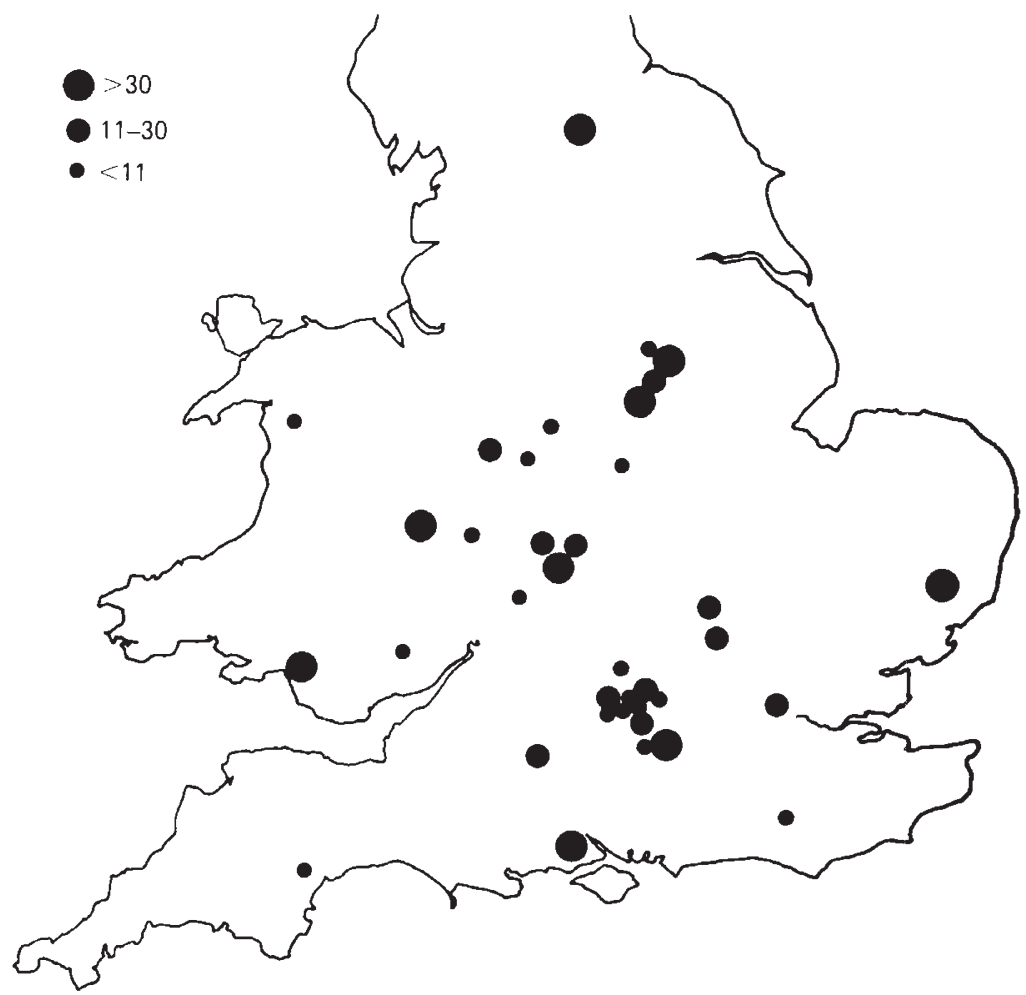

Figure 1 Sites in England and Wales from which fallow deer samples were obtained; size of circle indicates number of animals sampled.

Homogenates were centrifuged $(3000 \mathrm{rpm}$ for 15 minutes) and the supernatant was then used in electrophoresis.

Electrophoresis was carried out using a mixture of Shandon and home made equipment. General procedure for horizontal starch gel electrophoresis did not differ importantly from that described by Manlove et al. (1975). Buffer systems and stain recipes were taken from the literature or followed those in use in the laboratory of Professor R. J. Berry, University College London. In several cases more than one buffer system was tried. Preferred buffer systems, tissues used and references to detailed methods are given in table 2. Full details are given in Pemberton (1983).

Haemoglobin was focused in $0.3 \mathrm{~mm}$ thick 7 per cent acrylamide gels containing $p \mathrm{H} \mathrm{6-8}$ Ampholines (LKB) at a concentration of 0.2 per cent. Seventeen chroma Whatman paper was soaked in $1 \mathrm{M} \mathrm{H}_{3} \mathrm{PO}_{4}$ at the anode and $1 \mathrm{M} \mathrm{NaOH}$ at the cathode. Samples were loaded on pieces of $1 \mathrm{MM}$ filter paper laid on the surface of the gel. Voltage was applied via a focusing jacket made in the Zoology Department workshop.

The loci screened were chosen because they are known to be polymorphic in deer or other mammals, because they stain up at the same time as the "target" loci, or because they are cheap to stain or easy to resolve.

In a project with a fixed time limit, the number of loci which can be screened is inversely related to the number of individuals screened at each locus. In the present study, after the first few loci had been screened, calculations were made to help decide how many samples from the "sample bank" needed to be examined at a locus and found to be indistinguishable for that locus to be regarded as monomorphic. Taking a locus in which the rarer allele is at frequency 0.01 as a minimum criterion of polymorphism and assuming Hardy-Weinberg equilibrium, each individual examined gives a probability of 0.98 of not detecting such a polymorphism. The probability of detecting polymorphism is then $\left(1-0.98^{1}\right)=0.02$ after one sample, $\left(1-0.98^{10}\right)=0.18$ after 10 samples, etc. Whereas the probability of detecting polymorphism increases rapidly with the first few samples examined, the reward (in terms of increased probability of detecting polymorphism) in return for effort decreases as the probability approaches $1 \cdot 0$. In the present study, it was decided, somewhat arbitrarily, to try to examine at least 100 individuals 
Table 2 Electrophoresis methods and sample sizes used in the present study. Key: under "Tissues studied": $\mathrm{p}=$ plasma, h= haemolysate, $\mathrm{l}=$ liver, $\mathrm{k}=$ kidney, $\mathrm{m}=$ muscle; under "Reference and Method": gel concentration indicated as \%, poly.= polyacrylamide, disc. $=$ discontinuous buffer system

\begin{tabular}{|c|c|c|c|c|c|}
\hline Protein & $\begin{array}{l}\text { Reference and Method } \\
\text { (electrophoresis on } \\
\text { starch gels except } \\
\text { where stated) }\end{array}$ & $\begin{array}{l}\text { Tissues } \\
\text { studied }\end{array}$ & $\begin{array}{l}\text { No. of } \\
\text { loci }\end{array}$ & $\begin{array}{l}\text { No. of } \\
\text { animals }\end{array}$ & $\begin{array}{l}\text { No. of } \\
\text { study sites }\end{array}$ \\
\hline Tf (transferrin) & $\begin{array}{l}\text { Manlove et al. (1975). } 12.4 \% \text { lithium } \\
\text { hydroxide. }\end{array}$ & $\mathrm{p}$ & 1 & 368 & 13 \\
\hline Alb (albumin) & As for Tf & $\mathrm{p}$ & 1 & 368 & 13 \\
\hline $\operatorname{s} \alpha \mathrm{g}($ slow $\alpha$-globulin $)$ & As for $\mathrm{Tf}$ & $\mathrm{p}$ & 1 & 368 & 13 \\
\hline $\mathrm{Hb}$ (haemoglobin) & $\begin{array}{l}\text { After Lawton and Sutton (1981). Isoelectric } \\
\text { focusing, } 7 \% \text { poly. }\end{array}$ & $\mathrm{h}$ & 1 & 224 & 15 \\
\hline $\begin{array}{l}\text { GPD (glycerol-3-phosphate } \\
\text { dehydrogenase }\end{array}$ & $\begin{array}{l}\text { Harris and Hopkinson (1976). } 11 \% \text { tris- } \\
\text { EDTA-maleate }\end{array}$ & $1, \mathrm{k}$ & 1 & 88 & 13 \\
\hline $\begin{array}{l}\text { SDH (sorbitol dehydro- } \\
\text { genase) }\end{array}$ & Op't Hof et al. (1969). 12\% tris-phosphate. & 1 & 1 & 100 & 14 \\
\hline $\begin{array}{l}\text { LDH (lactate dehydro- } \\
\text { genase) }\end{array}$ & $\begin{array}{l}\text { Manlove et al. (1975). } 12 \cdot 4 \% \text { disc. tris- } \\
\text { citrate. }\end{array}$ & $\mathrm{m}$ & 2 & 134 & 18 \\
\hline $\begin{array}{l}\text { MDH (malate dehydro- } \\
\text { genase) }\end{array}$ & $\begin{array}{l}\text { Harris and Hopkinson (1976). } 11 \% \text { phos- } \\
\text { phate-citrate. }\end{array}$ & $\mathrm{k}, \mathrm{l}, \mathrm{m}$ & 2 & 109 & 17 \\
\hline $\begin{array}{l}\text { IDH (isocitrate dehydro- } \\
\text { genase) }\end{array}$ & As for $\mathrm{MDH}$ & $\mathrm{k}, \mathrm{l}, \mathrm{m}$ & 2 & 109 & 17 \\
\hline $\begin{array}{l}\text { 6-PGD (6-phosphogluconate } \\
\text { dehydrogenase. }\end{array}$ & $\begin{array}{l}\text { Harris and Hopkinson (1976), under ADA. } \\
11 \% \text { phosphate. }\end{array}$ & $\mathrm{I}, \mathrm{h}$ & 1 & 151 & 20 \\
\hline $\begin{array}{l}\text { GDH (glucose dehydro- } \\
\text { genase) }\end{array}$ & $\begin{array}{l}\text { Harris and Hopkinson (1976). } 11 \% \text { tris- } \\
\text { citrate. }\end{array}$ & 1 & 1 & 115 & 14 \\
\hline $\begin{array}{l}\text { G6PDH (glucose 6-phos- } \\
\text { phate dehydrogenase) }\end{array}$ & $\begin{array}{l}\text { After Ruddle et al. (1968) 13\% tris-EDTA- } \\
\text { borate. }\end{array}$ & $1, \mathrm{~h}$ & 1 & 132 & 15 \\
\hline $\begin{array}{l}\text { SOD (super-oxide dis- } \\
\text { mutase) }\end{array}$ & As for LDH and G6PDH. & $\mathrm{I}, \mathrm{m}, \mathrm{h}$ & 2 & 207 & 22 \\
\hline $\begin{array}{l}\text { GOT (glutamate oxaloace- } \\
\text { tate transamimase) }\end{array}$ & $\begin{array}{l}\text { DeLorenzo and Ruddle (1970). } 12 \% \\
\text { citrate-phosphate. }\end{array}$ & $\mathrm{k}, \mathrm{l}$ & 2 & 111 & 16 \\
\hline AK (adenylate kinase) & $\begin{array}{l}\text { Harris and Hopkinson (1976). } 11 \% \text { his- } \\
\text { tidine-citrate. }\end{array}$ & $\mathrm{k}, 1$ & 2 & 107 & 14 \\
\hline $\begin{array}{l}\text { PGM (phosphogluco- } \\
\text { mutase) }\end{array}$ & $\begin{array}{l}\text { Harris and Hopkinson (1976). } 11 \% \text { tris- } \\
\text { EDTA-maleate. }\end{array}$ & 1 & 2 & 105 & 15 \\
\hline Est (esterases) & As for $\mathrm{Tf}$. & $\mathrm{p}$ & 2 & 230 & 17 \\
\hline AP (acid phosphatase) & As for 6-PGD & $\mathrm{h}$ & 1 & 115 & 14 \\
\hline CA (carbonic anhydrase) & As for G6PDH & $\mathrm{h}$ & 2 & 107 & 9 \\
\hline $\begin{array}{l}\text { GPI (glucose phosphate } \\
\text { isomerase) }\end{array}$ & $\begin{array}{l}\text { Harris and Hopkinson (1976). 11\% tris- } \\
\text { citrate. }\end{array}$ & $\mathrm{k}$ & 1 & 101 & 16 \\
\hline
\end{tabular}

at each locus, giving a probability of 0.87 of detecting a borderline polymorphism. Table 2 shows the number of individuals examined for each system: the target of 100 was achieved for all except one system, GPD ( 88 samples, see table 2 ).

A related decision concerned which samples from the "sample bank" to examine. Previous genetic studies of deer species have revealed considerable between-population variation in the level of polymorphism detected (table 1). Preliminary enzyme surveys of moose and wapiti involving limited sampling of populations (Ryman et al., 1977; Cameron and Vyse, 1978) were taken to indicate that these species had unusually low levels of polymorphism, a finding which was not borne out by subsequent, more extensive surveys (Ryman et al., 1980; Dratch and Gyllensten, in press). To avoid such problems, each locus screened in the present study was examined in samples representing several sampling sites. Table 2 shows the number of sampling sites represented by the samples screened for each system.

Finally, to maximise the use made of samples, different combinations of samples were used in the screening of different loci.

\section{RESULTS}

Under the electrophoresis conditions employed, none of the presumed 30 loci screened in the fallow deer samples showed variation which could be interpreted on a genetic model. 
Broadly speaking, band patterns were as expected on the basis of previous studies of deer (e.g., Manlove et al., 1975). The following account uses the locus designations of Allendorf and Utter (1979) in which, when an enzyme is encoded by more than one locus, locus products are labelled from cathode to anode. In brief, IDH-2, G6PDH, SOD-2, Est-2 and Alb zymograms consisted of a single anodal band of high mobility; GPD, MDH2, GDH, SOD-1, GOT-2, AK-1 and -2, PGM-1 and $-2, \mathrm{CA}-1$ and -2 and slow $\alpha$-globulin zymograms consisted of a single anodal band of moderate mobility; IDH-1 and 6-PGD zymograms consisted of a single anodal band of low mobility. GOT-1 was revealed as a cathodal band of medium mobility while SDH and MDH-1 products formed a single cathodal band of low mobility. The remaining locus products formed more complex band patterns. LDH- 1 and -2 products combined in tetramers to form five isozymes ranging from the origin to the anode, as described in the whitetailed deer (Manlove, et al., 1975). Fallow deer transferrin consisted of a double-banded anodal system of moderate mobility, as described by McDougall and Lowe (1968). Double-banded anodal patterns were also observed for the plasma esterase system designated Est- 1 and for AP for which a similar band pattern has been described in other mammals (Harris and Hopkinson, 1976). As recorded by previous workers (Butcher and Hawkey, 1977; Lawton and Sutton, 1981), focused fallow deer haemoglobin also consists of two major bands. The GPI zymogram consisted of three evenly spaced anodal bands, a pattern also observed in other deer species which has prompted speculation that, in cervids, two GPI loci are expressed (Manlove et al., 1975; Ryman et al., 1977; Gyllensten et al., 1983), although there is as yet no firm evidence for this suggestion.

Certain enzymes (notably LDH, MDH, 6PGD, GOT and CA) tended to produce sub-bands after storage for several months. In the case of $\mathrm{LDH}$, treatment of the samples with dithiothreitol removed the sub-bands indicating that they were due to the formation of sulphydryl-glutathione bonds during storage (Harris and Hopkinson, 1976). Storage of haemolysates produced methaemoglobin bands which could be distinguished from the true haemoglobin bands by their brown colour. Blood samples arriving by post which had haemolysed in transit sometimes showed stepwise changes in transferrin band mobility giving an overall pattern like that which might be expected for a transferrin polymorphism. Experiments revealed that the variants were post-collection changes probably caused by bacterial growth while the samples were in transit (Lowe and McDougall, 1961). Results from posted blood samples were therefore excluded from the final figure for the number of individuals examined for transferrin given in table 2. Occasional aberrant results at other loci did not coincide with the band patterns expected for heterozygotes on the basis of the subunit structure known in other mammals and could usually be attributed to denaturing of the sample. A putative genetic polymorphism in the slow $\alpha$-globulin region of plasma was discounted on the basis of results from repeat bleedings of individual deer and from deer of known relatedness held in enclosures for breeding studies (Smith and Johnson, 1982).

While failing to reveal genetic polymorphism in the fallow deer samples, the electrophoresis systems detected previously described transferrin and IDH-2 polymorphisms in the red deer (McDougall and Lowe, 1968; Gyllensten et al., 1983) and a previously undescribed transferrin polymorphism in the Reeve's muntjac, involving two alleles. The $p \mathrm{H} \mathrm{6-8} \mathrm{isoelectric} \mathrm{focusing} \mathrm{unam-}$ biguously demonstrated foetal haemoglobin in neonatal fallow deer, repeated the finding of haemoglobin polymorphism in Reeve's muntjac (Maughan and Williams, 1967) and revealed variation in red deer haemoglobin patterns, not previously described.

\section{DISCUSSION}

The present study does not show that British fallow deer totally lack electrophoretically-detectable genetic variation. The survey involved a sample of loci, buffer systems, sites and individual deer. At each level a different or bigger sample might have led to the discovery of polymorphism. Nevertheless, given the sample sizes employed in the present study (see Materials and Methods) and assuming our electrophoresis was of equivalent resolving power to that of other workers in the field (in support of which we point to the polymorphisms found in red and muntjac deer) it appears likely that British fallow deer really do have a lower level of genetic variation than other deer species studied to date.

We know of no convincing selectionist theory predicting a low level of genetic variation in the fallow deer compared with other deer species. The "environmental grain" hypothesis of Selander and 
Kaufman (1973), which predicts low levels of variation in large, highly mobile species and vice versa has attracted some interest in the literature (e.g., Cameron and Vyse, 1978) but was not supported by a recent interspecific comparison of large grazing mammals (Baccus et al., 1983). Presumably the environmental grain hypothesis would predict a higher level of variation in fallow deer than in moose, red deer and wapiti, which is not borne out by our findings. We are therefore forced to the conclusion that the lack of variation found in the present study reflects a genetic bottleneck in the history of British fallow deer. Such a bottleneck might have occurred at a number of points in history.

First, a bottleneck might have occurred when the fallow deer was introduced to Britain. Palaeontological evidence suggests that the species died out in Britain during the last glaciation (Chapman and Chapman, 1975, p. 45). It is possible that the introduced animals were few in number and were forced to inbreed for several generations, losing genetic variation in the process (though this is by no means inevitable, cf. the Reeve's muntjac, another species introduced to Britain). A problem with this theory is that there are several documented introductions of fallow deer to Britain since Norman times, when the main introduction was probably made (Chapman and Chapman, 1975, p. 49). For example, introductions were made in 1612 from Norway, in 1661 from Germany (Shirley, 1867) and in the 19th Century from Denmark (Whitehead, 1950, p. 153). If continental European fallow deer have a higher level of electrophoretically detectable polymorphism it is surprising that polymorphism is not found in the British population as a result of introductions. In this context it is interesting to note that a recent survey of 13 loci in a sample of 35 German fallow deer failed to reveal intraspecific polymorphism (H.G. Scheil, personal communication). A more extensive study of continental European fallow deer is clearly desirable.

Alternatively, a genetic bottleneck might have occurred before the introduction of the fallow deer to Britain. Under this hypothesis, mainland European fallow deer would also have a low level of electrophoretically-detectable polymorphism. The idea calls for an examination of the species' earlier history.

It seems that during the last glaciation the European fallow deer went extinct not only in Britain, but also over much of Europe (Lister, 1984). Jarman (1972) reviews data on mammalian remains at 165 Mesolithic sites (i.e., dating from
10,000 to 5000 years before the present) distributed throughout Europe. Although red deer and roe deer (Capreolus capreolus) are the first and fourth most widely represented species respectively, there are no definite reports of fallow deer, suggesting the species was scarce or absent at that time. The oldest post glacial finds of European fallow deer are at early Neolithic sites (5000 to 4000 years B.P.) in Greece and Bulgaria (Chapman and Chapman, 1975 , p. 44). Subsequent evidence of the presence of fallow deer comes from Hittite, Greek and Roman artefacts (Zeuner, 1963, p. 430; Chapman and Chapman, 1975, p. 46) and these cultures appear to have fostered the increase and spread of the species. Indeed, it seems likely that the entire distribution of European fallow deer outside the South Eastern corner of Europe is due to introductions by man (Chapman and Chapman, 1980).

In the history outlined, there is no obvious date, from the time man started to transport and introduce fallow deer onwards, when a genetic bottleneck affecting the entire descendent population might have occurred. Two main possibilities therefore exist. First, perhaps a natural catastrophe such as the last glaciation, which left only a relict population of European fallow deer surviving in S.E. Europe for the interval 10,000 to 5000 years B.P., was the direct cause of the bottleneck. Alternatively, perhaps the most serious loss of genetic variation took place during enforced inbreeding when man first took the fallow deer into captivity, which was presumably sometime in the interval 10,000 to 3000 years B.P.

History does not relate which of these theories is more likely, but a feature of modern fallow deer may give a clue. European fallow deer have a widespread, genetically-controlled coat colour polymorphism, individuals ranging from all-white, through various spotted types, to all-black. It is difficult to understand how, in a bottleneck caused by the glaciation, coat colour variation could have been retained while electrophoretically-detectable variation was lost. On the other hand, coat colour variation is a notable characteristic of domestic animals (including the most highly domesticated deer species, the reindeer) and is believed to have been selected by man early in the domestication process (Zeuner, 1963). Although there is no information on the origin of the colour varieties of fallow deer, they are generally regarded as human selected (Chapman and Chapman, 1975, p. 73). It is possible that the coat colour varieties were expressed as a result of inbreeding during the initial domestication of fallow deer and were 
retained by man, while invisible variation (detectable now by electrophoresis) was lost.

The idea of a genetic bottleneck at least 3000 years ago often provokes suggestions that novel mutation would since have replaced lost variation. Calculation of how many mutations would be expected by now is hampered by lack of information, especially concerning the neutrality or otherwise of mutants and historical population size. However, if it can be assumed that fallow deer selection coefficients are comparable with those of other deer species, one approach is to examine the rate at which electrophoretically-detectable alleles arise and persist in other species of deer. Electrophoresis studies now exist which compare old and new world forms of moose (Reuterwall, 1980), red deer (Baccus et al., 1983; Dratch and Gyllensten, in press) and reindeer (Baccus et al., 1983) for which the last possible genetic contact (barring recent introductions) was roughly 10,000 years B.P., at the end of the glaciation. The data from these studies suggest that at a single locus, a detectable new mutation becomes established once in every 18,000 to 72,000 years. So, in a sample of 30 loci between one and five mutations would be expected to appear and persist in a 3000 year interval (details of the calculation are given in Pemberton, 1983).

Low as these rough estimates of detectable new mutations are, they should be reduced still further when the population size of fallow deer over the last few thousand years (affecting the absolute mutation rate) is taken into account. What evidence there is (Jarman, 1972, see above) suggests a far larger red deer than fallow deer population in Neolithic Europe. Present day fallow deer population estimates are frequently no more than guesses, but the figures are an order of magnitude smaller than those for red deer, moose and reindeer. Toth (1984), reviewing available estimates, puts the fallow deer population of the world excluding Britain at 164,000 . For Britain, Gibbs et al. (1975) guess at 50,000 wild fallow deer. Even allowing for enclosed fallow deer in Britain the world population estimate for the species would hardly equal the 255,000 red deer living in Scotland alone (Red Deer Commission, 1980). Such considerations suggest that the number of detectable mutations arising at 30 loci since the proposed fallow deer bottleneck could indeed be negligible.

Although we now know that it is wrong to generalise that all species of large mammal have low levels of variation, it does appear that a relatively high proportion of large mammals have little detectable polymorphism. Although additional sampling of populations would be desirable in some cases, it seems that the Northern elephant seal Mirounga angustirostris (Bonnell and Selander, 1974), the Atlantic walrus Odobenus rosmanus rosmanus (Simonson et al., 1982), the red fox Vulpes vulpes (Simonson, 1982), the beech marten Martes foina (Simonson, 1982), the polar bear Thalarctos maritumus (Allendorf et al., 1979; Larsen et al., 1983) and the cheetah (O'Brien et $a l ., 1983$ ) all show exceptionally low levels of variation as revealed by electrophoresis. Speculating on the cause of this lack of polymorphism, it is noticeable that excepting the fallow deer all the species with little detectable variation are carnivores. Baccus et al. (1983) suggested that "carnivorous species might be expected to have lower heterozygosities due to smaller average population size caused by their position in the trophic pyramid of numbers or the social structure of their populations," but immediately question the theory because the wolf Canis lupus (Fisher et al., 1976), the coyote Canis latrans (Fisher et al., 1976) and the Macquarie Island elephant seal Mirounga leonina (McDermid et al., 1972) all have relatively high average heterozygosities. The theory, of Baccus et al., is certainly unsatisfactory if one imagines that it is the mean population size of a species over a streich of time per se which determines the amount of genetic drift and hence affects the level of variation. However, in fact it is downward fluctuations in population size which cause the greatest loss of genetic variation. Therefore, low levels of variation may be expected in those species which maintain low population sizes and tend to fluctuate. Higher levels of variation are expected either where average population size is high or where fluctuations are rare.

Finally, we consider the possible consequences of a low level of variation for the fallow deer. First, the finding lends support to the idea that British fallow deer experience low levels of inbreeding depression (Smith, 1979) since it suggests that comparatively few recessive deleterious alleles would be expressed on inbreeding. Second, if one accepts that variation at loci detectable by electrophoresis (or at linked loci) is not selectively neutral, various predictions follow. In the context of deer farming, heritabilities of quantitative characters will be lower than in more polymorphic (as revealed by electrophoresis) species and selective breeding correspondingly less successful. Within-herd variance of production characters such as live weight is lower in fallow deer than in red deer on New Zealand deer farms, supporting this prediction $(\mathrm{G}$. Asher, personal communication). In the wild, fallow deer will not adapt to altered environmental 
conditions as successfully as other more polymorphic species. Here we point to the low estimated world population for fallow deer (discussed above), the lower rate of spread of introduced fallow deer compared with red deer in New Zealand (Caughley, 1963; Chapman and Chapman, 1980) and the perhaps rather subjective comment that in Britain the fallow deer has nowhere achieved the pest status of red or roe deer.

Acknowledgements J. Pemberton acknowledges support by the Science and Engineering Research Council and the Forestry Commission under the C.A.S.E. scheme. More than 50 people were involved in collecting samples, and we thank them all. We are also grateful for technical advice from Ray Nash (University College, London) and John Sutton (Home Office Central Research Establishment, Aldermaston).

\section{REFERENCES}

ALLENDORF, F. W., ('HRISTIANSEN, F. B., I)OBSON. T., EANES, W. F. ANI) FRYDENBER(;, O. 1979. Electrophoretic variation in large mammals I. The polar bear Thalarctos maritimus. Hereditas, 91, 19-22.

ALLENDORF, F. W. AND UTIER, F. M. 1979. Population Genetics. In Hoar, W. S., Randall, D. J. and Brett, J. R. (eds.) Fish Physiology 8, Academic Press, New York, pp. $409-454$.

AVIS1, J. C AND AQUADRO, C.F. 1982. A comparative summary of genetic distances in the vertebrates: patterns and correlations. Fvol. Biol., 15, 151-185.

BACCUS, R., HILI.ISTAI), H. O., JOHNS, P. E., MANI.OVE. M. N., MAR(HINTON, R. L. ANI) SMITH, M. H. 1977. Prenatal selection in white-tailed deer. Proc. Ann. Conf. S.E. Assoc. Game Fish Comm., 31, 173-179.

BACCUS, R., RYMAN, N.. SMITH, M. H., RHUTHEWAII, C. AND CAMIR()N, I). 1983. Genetic variability and differentiation of large grazing mammals. J. Mammal., 64, 109-120.

I3ONNELL, M. L. ANI) SEI ANDER, R. K. 1974. Elephant sealsgenetic variation and near extinction. Science 184,908-909.

BRAENI), M. 1962. Studies on the blood and serum groups of the elk (Alces alces). Ann. N.Y. Acad. Sci., 97, 296-305.

BRAEND, M. 1964. Genetic studies on serum transferrins in reindeer. Hereditas, 52, 181-188.

BUT( HI:R, P. I) AND HAWKLY, ( $\therefore$ M. 1977. A comparative study of haemoglobins from the artiodactyla by isoelectric focusing. Comp. Biochem. Physiol., 56B, 335-339.

CAMERON, I). (i. ANI) VYSE, E. R. 1978. Heterozygosity in the Yellowstone Park elk (Cervus canadensis). Biochem. Genet., 16, 651-657.

CAUGHLEY, (i. 1963. Dispersal rates of several ungulates introduced into New Zealand. Nature, 200, 280-281.

('HAPMAN, D. I. ANI) CHAPMAN, N. (i. 1969. Geographical variation in fallow deer. Nature, 221, 59-60.

ChapMan, 1). ANI) CHAPMAN, N. 1975. Fallow Deer: their history, distribution and biology. Dalton, Lavenham.

(HAPMAN, N. G., AND (:HAPMAN. D. 1. 1980. The distribution of fallow deer: a worldwide review. Mammal Review, 10, 61-138.

CHESSER, R. K., REUTYRWAI,. C. AND RYMAN, N. 1982. Genetic differentiation of Scandinavian moose Alces alces populations over short geographical distances. Oikos, 39, $125-130$.
COTHRAN, R. (i., CHESSER, R. K., SMITH, M. H. AND JOHNS, P. I: 1983. Influence of genetic variability and maternal factors on fetal growth in white-tailed deer. Evolution, 37 , 282-291.

DE LORK:NZO, R. J. ANI) RUDDLE, F. H. 1970. Glutamate oxalate transaminase (GOT) genetics in Mus musculus: linkage, polymorphism and phenotypes of the GOT-2 and GOT-1 loci. Biochem. Genet., 4, 259-273.

DRATCH, P. AND (IYII.ENSTEN, U. In press. Genetic differentiation of red deer and North American elk (wapiti): evidence for subspecific status. In Fennessy, P. and Drew, K. (eds.) The Biology of Deer Production.

FISHER, R. A., PUTT, W. AND HACKEL, I: 1976. An investigation of the products of 53 gene loci in three species of wild Canidae: Canis lupus, Canis latrans and Canis familiaris. Biochem. Genet., 14, 963-974.

(IIBBS, I. B. 3. HERNIMAN, K. A. I., LAWMAN, M. J. P. ANI) StLli:Rs, R. F. 1975. Font-and-mouth disease in British deer: transmission of virus to cattle, sheep and deer. Vet. Rec., 96, 558-563.

GYLLENSTEN, U, RYMAN, N., REUTRRWALL, C. ANI) 1) RATC H, P. 1983. Genetic differentiation in four European subspecies of red deer (Cervus elaphus L.). Heredity, 51, $561-580$.

HARRIS, H. AND HOPKINSON, D. A. 1976. Handbook of enzyme electrophoresis in human genetics. North-Holland Publishing Co., Amsterdam.

JARMAN, M. R. 1972. European deer economies and the advent of the Neolithic. In Higgs, E. S. (ed.) Papers in Economic Prehistory, Cambridge University Press, Cambridge, pp. $125-147$.

JOHNS, P. E., BACCUS, R., MANLOVE, M. N., PINDER, J. F. II ANI) SMITH, M. H. 1977. Reproductive patterns, productivity and genetic variability in adjacent white-tailed deer populations. Proc. Ann. Conf. S.E. Assoc. Game Fish Comm., 31, 167-172.

JOHNSON, M. I. 1968. Application of blood protein electrophoretic studies to problems in mammalian taxonomy. Syst. Zool., 17, 23-30.

I.ARSON, T., TEGELSTROM, H., JUNEJA, R. K. ANI) TAYLOR, M. K. 1983. Low protein variability and genetic similarity between populations of the polar bear (Ursus maritimus). Polar Res., 1, 97-105.

LAWTON, M. K. ANIS SUITTON, J. G. 1981. Species identification of deer blood by isoelectric focusing. Deer, 5, 285-288.

I.ISTIR, A. M. 1984. Evolutionary and ecological origins of British deer. Proc. roy. Soc. Edinburgh 82B 205-229.

LOWE, V. P'. W., ANI) MA( DOUGALl, E. I. 1961. Serum $\beta$ globulin types in red deer and other species and their stability in the presence of bacteria. Nature, 192, 983-984.

M( (I.YMONT, R. A., FENTON, M. ANI) THOMPSON, J. R. 1982. Identification of cervid tissues and hybridization by serum albumin. J. Wildl. Manage., 46, 540-544.

M(I)IRMII), E. M., ANANTHAKRISHNAN, R. AND AGAR, N.S 1972. Electrophoretic investigation of plasma and red cell proteins and enzymes of Macquarie Island elephant seals. Anim. Bld. Grps. Biochem. Genet., 3, 85-94.

M(i)OUGALL, E. I. ANI) LOWI, V. P. W. 1968. Transferrin poly morphism and serum proteins of some British deer. J. Zool. Lond., 155, 131-140.

MANLOVI, M. N., AVISE, J. C., HIII.ESTAD, H. O., RAMSEY, P. R., SMITH, M. H. AND STRANEY, D. O. 1975. Starch gel electrophoresis for the study of population genetics in white-tailed deer. Proc: Ann. Conf. S.E. Assoc. Game Fish Comm., 29, 392-403.

MANLOVE, M. N., SMITH, M. H., HILLESTAD, H. ()., HULLER, S E., JOHNS, P. F. AND STRANEY, D. O. 1976. Genetic sub- 
division in a herd of white-tailed deer as demonstrated by spatial shifts in gene frequencies. Proc. Ann. Conf. S.E. Assoc. Game Fish Comm., 30, 487-492.

MAUGHAN, E. AND WILliams, J. R. B. 1967. Haemoglobin types in deer. Nature, 215, 404-405

MUNDAY, B. L., CORBOULD, A., AND GOODSALL, G. 1974. Identification of muscle tissue from mammals. $J$. Wildl. Manage., 38, 884-886.

NEVO, E. 1978. Genetic variation in natural populations: pattern and theory. Theoret. Pop. Biol., 13, 121-177.

OATES, D., PEARSON, K. AND DENT, N. 1979. Differentiation of white-tailed and mule deer blood and tissue by isoelectric focusing. Nebraska Game and Parks Commission 1979 Project W-38R.

O'BRIEN, S. J., WILDT, D. E., GOLDMAN, D., MERRIL, C. R. AND BUSH, M. 1983. The cheetah is depauperate in genetic variation. Science, 221, 459-462.

OPT'T HOF, J., WOLF, V. AND KRONE, W. 1969. Studies on isozymes of sorbit dehydrogenase in some vertebrate species. Humangenetik, 8, 178-182.

PEMBERTON, J. M. 1983. An investigation into the population genetics of British fallow deer (Dama dama L.). Ph.D. thesis, University of Reading.

POWELL, J. R. 1975. Protein variation in natural populations of animals. Evolutionary Biology 8, ed. T. Dobzhansky, M. K. Hecht, and W. C. Steere, 79-119. Plenum, New York.

RAMSEY, P. R., AVISE, J. C., SMITH, M. H. AND URBSTON, D. F. 1979. Biochemical variation and genetic heterogeneity in South Carolina deer populations. J. Wildl. Manage., 43, 136-142.

RED DEER COMMISSION 1980. Annual Report for 1979. H.M.S.O., London.

REUTERWALL, C. 1980 . Genetic variation in a large game species, the moose (Alces alces): patterns of differentiation and some management implications. Ph.D. thesis, University of Stockholm.

RØED, K. H. In press. Genetic differences at the transferrin locus in Norwegian semi-domestic and wild reindeer (Rangifer tarandus L.) Hereditas.

RUDDLE, F. H., SHOWS, T. B. AND RODERICK, T. H. 1968. Autosomal control of an electrophoretic variant of glucose6-phosphate dehydrogenase in the mouse (Mus musculus). Genetics, 58, 599-606.

RYDER, O. A., BRISBIN, P. C., BOWLING, A. T. AND WEDEMEYER, E. A. 1981. Monitoring genetic variation in endangered species. In Scudder, G. G. E. and Reveal, J. L. (eds.) Evolution Today, Proceedings of the second international Congress of systematic and evolutionary Biology, pp. 417-424.

RYMAN, N., BECKMAN, G., BRAUN-PETERSON, G. AND REUTERWALL, C. 1977. Variability of red cell enzymes and genetic implications of management policies in Scandinavian moose (Alces alces). Hereditas, 85, 157-162.

RYMAN. N., REUTERWALL, C., NYGREN, K. AND NYGREN, T. 1980. Genetic variation and differentiation in Scandinavian moose (Alces alces): are large mammals monomorphic? Evolution, 34, 1037-1049.
SEAL, U. S. AND ERICKSON, A. W. 1969. Hematology, blood chemistry and protein polymorphisms in the white-tailed deer (Odocoileus virginianus). Comp. Biochem. Physiol., 30, 695-713.

SELANDER, R. K. AND KALFMAN, D. W. 1973. Genic variability and strategies of adaptation in animals. Proc. natl. Acad. Sci. U.S.A., 70, 1875-1877.

SHIRLEY, E. P. 1867. Some account of English deer parks with notes on the management of deer. John Murray, London.

SIMONSEN, v. 1982. Electrophoretic variation in large mammals 1I. The red fox, Vulpes vulpes, the stoat, Mustela erminea, the weasel, Mustela nivalis, the pole cat, Mustela putorius, the pine marten, Martes martes, the beech marten, Marten foina, and the badger, Meles meles. Hereditas, 96, 299-305.

SIMONSEN, V., BORN, E. W. AND KRISTENS, T. 1982. Electrophoretic variation in large mammals 4. The Atlantic walrus, Odobenus rosmarus rosmarus (L.). Hereditas, 97, 91-94.

SMITH, M. H., BACCUS, R., HILLESTAD, H. O. AND MANLOVE, M. N. In press. Population genetics of the white-tailed deer. In Halls, L. (ed.) Ecology and Management of White-tailed Deer, Stackpole Books, New York.

SMITH, M. H., CHESSER, R. K., COTHRAN, E. G. AND JOHNS, P. E. 1982. Genetic variability and antler growth in a natural population of white-tailed deer. Proc. int. Symp. on Antler Development in Cervidae, Caeser Kleberq Foundation.

SMITH, M. H., HILlestAD, H. O., MANLOVE, M. N. AND MARCHINTON, R. L. 1976. Use of population genetics data for the management of fish and wildlife populations. In Sabol, K. (ed.) Trans. 41st N. American Wildlife and Natural Resources Conf., Washington.

SMITH, R. H. 1979. On selection for inbreeding in polygynous animals. Heredity, 43, 205-211.

SMITH, R. H. AND JOHNSON, E. 1982. Long-haired fallow deer. Rep. Forest Res., Edin. 1982, 52-53.

SOLDAL, A. V. AND STAAL.AND, H. 1980. Genetic variation in Norwegian reindeer. In Proc. 2nd Int. Reindeer/Caribou Symp., Roros, Norway, 1979, ed. E. Reimers, E. Gaare, and S. Skjenneberg. Direktoratet for vilt Ogferskvannfisk, Trondheim.

TOTH, S. 1984. Evaluation of the world fallow deer population. Paper presented at the C.I.C. Fallow Deer Symposium, Budapest, Jan. 1984.

TURUBANOV, M. N. AND SHUBIN, P. N. 1971. New alleles of the transferrin locus in reindeer. Genetika, 7, 171-173 (English translation Trans. Soviet Genet., 7, 265-266.)

WHITEHEAD, G. K. 1950. Deer and their Management in the Deer Parks of Great Britain and Ireland. Country Life, London.

ZEUner, F. E. 1963. A History of Domesticated Animals. Hutchinson, London.

ZHURKEVICH, N. M. AND FOMICHEVA, I. I. 1976. Genetic polymorphism of transferrins of blood serum in reindeer (Rangifer tarandus L.) indigenous to North-Eastern Siberia. Genetika, 12, 56-65 (English translation Trans. Soviet Genet., 12, 37-44. 